\title{
Strategic Integration of Integrated Marketing Communications,
}

\section{Case of Croatia}

\author{
Bilić, I. ${ }^{1 *} \&$ Mateljak, Ž. ${ }^{1}$ \\ ${ }^{1}$ Faculty of Economics, University of Split, Split, Croatia \\ *Bilić, I., E-mail: ibilic@efst.hr
}

\begin{abstract}
The main purpose of this paper is to investigate the relationship between the development of integrated marketing communications, corporate communication strategy and its alignment with overall corporate strategy in Croatian companies. In addition, in Croatian business environment, particularly in the period of economic crisis, companies try to reduce their costs, which results in neglecting the communication function. There is also the eternal scientific question regarding the effects of investment in marketing and communication functions. Therefore, this question will be discussed in this paper by observing the correlation between integrated marketing communications and organizational performances reached by observed companies.

It is presumed that there is a positive relationship between higher levels of developed integrated marketing communications and organizational performance, which the observed companies achieved. This survey was conducted on 500 companies with the highest value added rank in the Republic of Croatia in the year 2009 (according to the Institute for Business Intelligence).
\end{abstract}

Keywords

corporate strategy, corporate communications, integrated marketing communications, organizational performances

\section{Introduction}

Integrated marketing communications (hereinafter IMC will be used) is observed through its elements such as: personal selling, brand advertising, corporate advertising, sales promotion, publicity, Internet promotion, sponsorship, and events. In this research, coordinating IMC with the marketing department and consulting with the company's top management about IMC will also be taken into consideration.

Therefore, the aim of this paper is to provide the evidence of the relationship and the nature of the relationship between the level of IMC's development and corporate communication strategy, i.e., general corporate strategy in Croatian companies. In the following phase of this research our efforts will be concentrated on finding evidence of the correlation between the elements and activities of IMC and organizational performances such as revenue, profit, and value added.

Corporate communications as a management function should be considered as a very important strategic function in modern management. Corporate communications as a management function need to incorporate all aspects and forms of communication with a wide polygon of different and complex internal and external companies' stakeholders.

Aiming at obtaining the adequate answer to the problem considered, this paper defines a next hypotheses investigation:

H1: there is a positive relationship between higher levels of integrated marketing communications activates and organizational performance which observed companies achieved. 
This survey has been conducted on the population of 500 companies with the highest value added rank in the Republic of Croatia in the year 2009 (according to the Institute for Business Intelligence). Analyzed are companies with corporate communication executives to assess activities and the level of development of IMC in their companies.

IMC, as an important component of total corporate communications, were treated trough questionnaire which included 10 questions. Eight of surveyed questions examined elements of IMC, and last two questions has been used to provide evidence of connections between important IMC elements, giving their opinions (among other) on questions about companies practices related to IMC through a five-grade Likert scale (1- not at all; 2-very little; 3-some, 4-much, 5-completely).

Besides determining the interrelation between levels of integrated marketing communications activates and organizational performance, the goal of this paper is to achieve the following objectives:

-to determine the level of development of IMC elements,

-to determine activities in line with corporate strategy and corporate goals,

-to determine correlations between IMC elements/activities and corporate strategy and corporate goals, -to determine correlations between IMC and organizational performances in 2010., and

-to determine correlations between IMC and organizational performances in 2007.

In order to investigate the above mentioned hypothesis, the reminder of the paper is organized in three sections. The first section gives an overview of previously conducted research on IMCs, corporate communications strategy and corporate strategy, focusing on interdependencies. In the second section of this paper, the research methodology, data collecting process and research results will be presented. In the third section, authors will offer research conclusions and certain limitations of this research.

\section{Integrated Marketing Communications}

IMC has been an area of academic interests since the early 1990s (Laurie \& Mortimer, 2011). Marketing communications has an important role in driving the corporate message both externally and internally as well as aligning corporate image with the social identity. Marketing communications support the institutionalization of the organization by rationalizing its existence through corporate advertising and by legitimizing the outputs of the organization through branding management (Belasen, 2008). Marketing communications support sales of products, services, and brands (van Riel \& Fombrun, 2007). Laurie and Mortimer (2011) perceive IMC as a marketing or marketing communications function rather than a corporate function and do not acknowledge the customer-centric approach.

Academic literature as usual provides researchers with a multitude of definitions for any term, IMC included. Thus, according to Smith, Berry and Pulford (2002) pointed three key definitions of IMC:

-The management and control of all market communications,

-Ensuring that the brand positioning, personality and messages are delivered synergistically across every element of communication and are delivered from a single consistent strategy,

-The strategic analysis, choice, implementation and control of all elements of marketing communications which efficiently, economically and effectively influence transaction between an organization and its existing and potential customers, consumers and clients.

Kliatchko (2008) provides a new definition of IMC: "an audience-driven business process of strategically managing stakeholders, content, channels, and results of brand communication programs". The main elements of IMC are: brand advertising, corporate advertising, public relations, sales promotions, point of purchase, packaging, exhibitions, sponsorship, Internet and social media, direct marketing, personal selling, corporate identity, word of mouth (Smith et al., 2002) and at present web 
word of mouth. IMC as a concept of marketing communication planning recognizes the "added value" (Cornelissen, 2008). The size of the company is not considered as a limiting factor in the marketing game, and every strategic principle and tactics could be used in small or large companies (Schultz, 2000). Van Riel and Fombrun (2007) defined marketing communications as a group responsible for communicating with the company's customer accounts and often interfaces with marketing and customer service function in the company.

\section{Corporate Communications and Corporate Strategy}

Corporate communication is the term used to describe a variety of strategic management functions Goodman (2004, 2006) positioned on the top management level (Dolphin, 2002; Goodman, 1998; Grunig, L. 2000; Kitchen, 1997; Steiner, 2001). Corporate communications as a function integrate communications efforts in building and maintaining relationship with companies' stakeholders, particularly, with its key stakeholders such as customers, investors, employees, media, etc. Having analyzed the list of key influential stakeholders, the authors in the field of corporate communication (Argenti, 2006; Cornelissen, 2008; Goodman, 1998, 2000) have agreed that corporate communication function includes the following elements: investor relations, media relations, employee relations, government relations or public affairs, marketing communication, corporate reputation, public relations, community relations, advertising, labor relations, government relations, technical communications, training and employee development, and management communications. Kitchen (1997) sees corporate communications as a system in which all communications specialists (marketing communications, organizational communications and management communications) integrated the totality of the organizational message intentionally. In their discussion regarding strategy and communication Rindova and Fombrun (1999) concluded that companies can build their competitive advantage by managing communications.

There is a widespread belief in the professional world that in today's society the future of any one company depends critically on how it is viewed by key stakeholders such as shareholders and investors, customers and consumers, employees, and members of the community in which the company resides. IMC has been the focus of many researches, and some of the most interesting and most relevant for this survey are presented in the following paragraphs.

The most interesting research for the strategic aspect of this research was Einwiller and Boenigk (2009) research. They examined the link between integrated communication management and communication effectiveness on a sample of 642 medium-sized enterprises in Switzerland, and provided empirical evidence for the effectiveness of written communication concepts and messages, the alignment of communication with corporate strategy and mission.

Rindova and Fombrun (1999) surveyed the role of the overall corporate communication function in strategy implementation and in the enhancing companies' brads and reputation. Chang (2009) examined cross-national IMCs on the web, analyzing the content of leading brands' sites across the USA, Taiwan, and China. Halliburton and Ziegfeld (2009) researched how major European corporations communicate their corporate identity across countries via official corporate websites. Benoit's theory of image restoration typology and its potential was used in analyzing management's communication strategies in financial reporting by researchers Erickson, Weber and Segovia (2011). Kim (2011) surveyed effects of transferring Corporate Social Responsibility strategy on consumer response, with synergy of corporate communication strategy. Šerić, Gil-Saura and Ruiz-Molina (2014) proved a positive effects of perceptions of IMC and brand image, perceived quality and brand loyalty. 
Bochenek and Blili (2013) highlighted that current trends in corporate communication researches are more concentrated on reputation, bottom line focus, corporate social responsibility, stakeholders' dialogue, and organizational cultures.

Considering all above, the field of corporate communication and valued IMC are important parts and strategic aspects of the overall corporate communication function. There is however a lack of research into the strategic position of IMC, particularly in Croatia. In this research, we search for empirical evidences of the development of IMC function in Croatian companies, and relations among the previously mentioned variables. To be more precise, we observed the relations between the development of IMC elements, activities and the development of corporate communications strategy and connections between corporate strategy and corporate goals.

\section{Research Methodology and Findings}

The overarching research theses addressed in this study are: the level of development of IMC elements and activities in Croatian companies; the relationship between corporate strategy and corporate communication strategy with IMC in Croatian companies. In the last step of our survey, researchers provided evidence of the relationship between the level of development of IMC elements and activities on the one hand and organizational performances reached by observed Croatian companies on the other.

This research was part of a wider research into the position and development of corporate communications function in Croatian companies conducted in 2011 (Bilić, 2011). A hard copy questioner, send by regular post, was employed to collect data from the heads of corporate communication in observed Croatian companies, to assess the development of elements and activities in their companies using their personal/professional judgment. IMC, as an important component of total corporate communications, was analyzed using 10 questions. Eight of the questions examined the IMC elements and the last two questions were used to provide evidence of activities which serve as a connection between IMC and corporate strategies. Communication executives gave their opinions (among other) through the five-point Likert scale (1-not at all; 2-very little; 3-some; 4-much; 5-completely) was used to find out the opinion of communication executives on.

Out of the total of 500 questionnaires sent, 70 were returned giving a response rate of $14 \%$ which can be accepted as relevant in social surveys. The respond rate of $14 \%$ can be accepted as relevant in social surveys (Fombrun \& Rindova, 1998).

The authors decided to summarize the main results of the research under the following three stages: first, the level of development of IMC in Croatia, second, the correlations between IMC elements/activities on the one hand and corporate strategy and corporate goals on the other, and last but most valuable for scientist and practitioners in the field of IMC, the correlation between IMC and organizational performances.

The results of our survey showed that in the observed companies the average level of corporate communications strategy development is 3.36 with the Mode (the most frequent value) of 4. Furthermore, the coordination of corporate communications strategy with corporate strategy showed an average level of 3.43 and Mode of 4.

The reliability analysis of the questionnaire for the observed variables (presented in Table 1) was conducted with the purpose to provide the researchers evidence about the reliability of the questioner which was in charge in this research. According to the Cronbach's Alpha reliability statistics, it is clear 
that the questionnaire was consistent and reliable instrument for the IMC analysis, with the Cronbach's Alpha score of 0.911 , higher than the necessary 0.7 .

Table 1. The Level of Development of IMC Elements and Activities in Line with Corporate Strategy and Corporate Goals

\begin{tabular}{lllll}
\hline Elements of IMC & N & Missing & Mean & Mode \\
\hline Internet release & 67 & 3 & 3.75 & 4 \\
Publicity & 67 & 3 & 3.52 & 3 \\
Corporate advertising & 66 & 4 & 3.48 & 3 \\
Sales promotion & 65 & 5 & 3.42 & 4 \\
Brand advertising & 65 & 5 & 3.42 & 4 \\
Sponsorship & 68 & 2 & 3.40 & 3 \\
Events & 65 & 5 & 3.18 & 3 \\
Personal selling & 65 & 5 & 2.95 & 4 \\
Consulting and Coordinating with the & 63 & 7 & 4.00 & 5 \\
Marketing department & & & & \\
Counseling Top Management (in terms of IMC) & 65 & 5 & 4.15 & 5 \\
\hline
\end{tabular}

Source: Research results.

IMC was observed through the main elements such as: personal selling, brand advertising, corporate advertising, sales promotions, publicity, Internet release, sponsors/donations and companies events. IMC activities were observed using two questions: consulting and coordinating of IMC with the marketing department and the power of corporate communications professionals to consult top management in relation of IMC. The results of descriptive statistics presented in Table 1 revealed that the Internet release (3.75 average grade) is the best developed element of IMC in Croatian companies and the element of personal selling is the least developed.

Furthermore, Mode for all observed elements of IMC led as to the conclusion, that there is some or considerable coordination between the observed phenomenon in Croatian companies. Answers to the question on consulting and coordinating IMC activities with marketing department undertaken by corporate communications executives, showed a high level of 4-much and Mode of 5. That means that in Croatian companies corporate communication executives work together with the marketing department. Furthermore, the average level on the second activities, i.e., "consulting top management" in Croatian companies is even higher, 4.15 with the Mode of 5. The results provided a valuable insight that in Croatian companies, corporative communications executives highly appreciate IMC and that they are aware of interconnections of those activities with overall communication and corporate strategy on the level of top management. Research results also showed that corporate communications strategy is less developed in 14 companies (20\%) and fully developed in only 10 companies.

In his research Goodman (2000) found out that $38.7 \%$ of corporate communication executives used vendors and agencies for marketing communications purpose. In the case of Croatia (Bilic, 2011) that proportion is even higher. A total of $52.86 \%$ of Croatian companies used vendors and agencies for IMC (brand and corporate advertising are included in this proportion).

IMC is perceived as having an impact on different levels of an organization, but its ultimate stage is proposed to be at a corporate or strategy level where its impact is felt right across the organization (Holm, 2006). In our research, we were motivated to find empirical evidence of interdependencies 
between strategically performed IMC and corporate strategy. The correlation between the elements and activities of IMC are presented in Table 2, and the results give us deeper insights into the connections between the observed relations. First relation: corporate communication officers consulting and coordinating activities with marketing department showed significant correlations with all the observed elements, represented with statistically significant correlations on the level of $1 \%$, with the highest correlation with brand advertising. Furthermore, last correlation with coordination between corporate strategy and corporate communications strategy is light and can be accepted with one flexible limit of $10 \%$.

Second surveyed relation was between IMC and activities corporate communication officers "consulting top management about IMC' showed low and significant correlation (5\%) with brand advertising and counseling and coordinating with the marketing department. Regarding the activities referred to as the "development of corporate communications strategy" and "coordination between corporate strategy and corporate communications strategy" correlation is significant at the level of $1 \%$ and lower.

The third relation we observed was the development of corporate communication strategy and IMC elements, and found significant correlations (at the level of 1\%) and mostly strong correlations with the highest score on the relations between developed strategy and publicity, with the Spearman's rho 0.751. The correlations between the development of corporate communications strategy and coordination between corporate strategy and corporate communications strategy showed strong Spearman's rho 0.820 and statistically significant correlation at the level of $1 \%$.

Last observed relations examined the relations between the elements of IMC and coordination between corporate strategy and corporate communications strategy. The results lead to an obvious conclusion that the development of corporate communications strategy is condition sine qua non for coordinating corporate strategy and corporate communications strategy. That relation reveals that almost all observed elements of IMC showed a significant correlation between the observed phenomena except the coordination with the marketing department.

One of the crucial questions for communication scholars are the effects of their efforts in terms of participation of achieved organizational performances (Argenti, 2006; Bütschi \& Steyn, 2006; Goodman, 2006; 2007; Grunig, 1990 etc.). In the final step of this survey we decided to investigate the link between the higher level of development of IMC and its effects on the organizational performance which observed companies achieved, we started from the assumption that there is a positive correlation between the observed phenomena. We also assumed that companies with higher score in total IMCs achieved higher organizational performance in observed companies.

Table 2. Correlations between IMC Elements/Activities and Corporate Strategy and Corporate Goals

\begin{tabular}{lllll}
\hline IMC strategy and: & 1 & 2 & 3 & 4 \\
\hline Personal Selling & $0.497^{* *}$ & 0.148 & $0.575^{* *}$ & $0.555^{* *}$ \\
Brand Advertising & $0.563^{* *}$ & $0.288^{*}$ & $0.604^{* *}$ & $0.571^{* *}$ \\
Corporate Advertising & $0.475^{* *}$ & 0.162 & $0.677^{* *}$ & $0.627^{* *}$ \\
Sales Promotions & $0.456^{* *}$ & 0.200 & $0.716^{* *}$ & $0.673^{* *}$ \\
Publicity & $0.459^{* *}$ & 0.177 & $0.751^{* *}$ & $0.633^{* *}$ \\
Internet Release & $0.431^{* *}$ & 0.146 & $0.456^{* *}$ & $0.388^{* *}$ \\
Sponsorship & $0.438^{* *}$ & 0.122 & $0.613^{* *}$ & $0.555^{* *}$ \\
\hline
\end{tabular}




\begin{tabular}{|c|c|c|c|c|}
\hline Events & $0.339^{* *}$ & 0.129 & $0.681^{* *}$ & $0.648^{* *}$ \\
\hline Consulting and Coordinating with the Marketing department & 1.000 & $0.318^{*}$ & $0.372^{* *}$ & 0.244 \\
\hline Consulting Top management & $0.318^{*}$ & 1.000 & $0.261^{*}$ & $0.309^{*}$ \\
\hline Development of corporate & $0.372^{* *}$ & $0.261^{*}$ & 1.000 & $0.820^{* *}$ \\
\hline \multicolumn{5}{|l|}{ Communication Strategy } \\
\hline $\begin{array}{l}\text { Coordination of CC strategy } \\
\text { with corporate strategy }\end{array}$ & 0.244 & $0.309^{*}$ & $0.820^{* *}$ & 1.000 \\
\hline
\end{tabular}

Source: Research results.

**Statistically significant at the level of 0.01 ,

* Statistically significant at the level of 0.05 ,

Legend: 1-Corporate communication officers counseling and coordinating activities with the marketing department; 2-Corporate communication officers consulting top management about IMC; 3-the development of corporate communications strategy; 4-Coordination between corporate strategy and corporate communications strategy.

Regarding our assumption that there is positive link between higher levels of IMC in observed companies and achieved organizational performances, precisely value added, revenue and profit, the results are shown in Table 3. For this purpose latent variables were obtained as average percentages of the observed elements and activities. The first latent variable presents the average score of IMC elements, the second one refers to IMC activities and a third one represents the total of IMC.

We found out that IMC elements (personal selling, sponsorships etc.) showed low and statistically significant correlation (1\%) for revenue and profit in 2010. IMC activities (coordination with the marketing department and consulting the top management) showed low and statistically significant correlation (1\%) for value added and revenue. Finally, the total IMC (elements and activities) showed statistically significant (1\%) and low correlations with revenue and profit.

Table 3. Correlations between IMC and Organizational Performances in 2010

\begin{tabular}{lllll}
\hline & & VA 2010 & Revenue 2010 & Profit 2010 \\
\hline \multirow{2}{*}{ Spearman's rho } & & & & $0.392^{* *}$ \\
& & & & $0.402^{* *}$ \\
& IMC activities & $0.370^{* *}$ & $0.485^{* *}$ & 0.253 \\
& IMC total & 0.219 & $0.406^{* *}$ & $0.362^{* *}$ \\
\hline
\end{tabular}

Source: Research results.

**Statistically significant at the level of 0.01 .

Furthermore, we took in consideration the impact of recession on the observed organizational performances, so we examined the same relations in the prerecession period, precisely in 2007. In the next stage of the survey, we compared secondary data for the organizational performances such as revenue, profit and value added for 2010 and 2007, as an effort to avoid effects of global recession which had a strong impact on Croatian economy. The results reveal even stronger connections among the observed phenomena (Table 4) in the prerecession period. 
Table 4. Correlations between IMC and Organizational Performances in 2007

\begin{tabular}{lllll}
\hline & & VA 2007 & Revenue 2007 & Profit 2007 \\
\hline \multirow{2}{*}{ Spearman's rho } & & & & \\
& & & & \\
& IMC elements & $0.350^{* *}$ & $0.408^{* *}$ & \\
& IMC total & $0.312^{* *}$ & $0.418^{* *}$ & $0.307^{*}$ \\
\hline
\end{tabular}

Source: Research results.

**Statistically significant at the level of 0.01 .

* Statistically significant at the level of 0.05 .

According to the results of the Spearman's coefficient of correlation, all the observed relations showed statistically significant correlation between the observed variables with the special attention to profit and IMC elements and total IMC, where we found strong and statistically significant correlation at the level of $1 \%$. Main implication of these results for Croatian practitioners is proof that higher level of IMC development can lead them to higher organizational performance and vice versa, companies with higher level of organizational performances pay more attention and are more aware of the importance of IMC.

\section{Conclusion and Limitations}

Previous researches led us to the assumption that there was an important relation between the elements and activities of corporate communications and corporate strategy. Although there are many researches in the field of corporate communications and IMC, there is a lack of evidence of research of that particular relationship, also there is a great lack of empirical evidence of correlations between communication functions and organizational performances.

Authors around the world agreed that better, more developed corporate communications, and IMC as part of the function, can have a positive influence on organizational performance. We conducted this research to provide evidence of correlations between the development of IMC and connections of the IMC with communication and corporate strategy. Finally, we were interested in examining the correlation between higher level of IMC and effects on corporate performances, to assure practitioners with arguments concerning it.

According to the research results, coefficient of correlation showed significant and high correlation between integration of IMC and revenue and profit, and VA in prerecession period. Furthermore, main implication of these results for Croatian practitioners is proof that higher level of IMC development can lead them to higher organizational performance and vice versa, companies with higher level of organizational performances pay more attention and are more aware of the importance of IMC.

We are also aware that all surveys have their limitations. The first limitation in this study could be the polygon of research, Croatian business environment in the period of deep recession what can strongly affect the observed function and we are sure that organizational performances, presented in our paper are influenced by deep recession. We tried to mitigate that effect with the usage of historical data (2007), but we are aware that in recession many of the observed companies can cut functions they see as being minor such as communication function.

To conclude, in a for future research a wider polygon or comparative research of several countries around the globe or at least more developed country (at least European countries) in terms of communication functions will give us more interesting results. Furthermore, our respondents were 
corporate communications executives, so answers on our questionnaire can represent their subjective point of view regarding all the observed phenomena, except organizational performances.

This research could be observed as a good trace for future research where researchers can scratch a bit deeper in the nature of observed relations, with more detailed questions, which will be less dependent on the subjective assessment of any professionals.

\section{References}

Argenti, P. A. (2006). Communications and business value: Measuring the link. Journal of business strategy, 27(6), 29-40.

Argenti, P. A. (2006). How Technology Has Influenced the Field of Corporate Communication. Journal of Business and Technical Communication, 30(3), 357-370.

Belasen, A. T. (2008). The theory and practice of corporate communication: A competing values perspective. Los Angeles: Sage publication.

Bilić, I. (2011). Strateško pozicioniranje korporativnih komunikacija, reputacije i organizacijskih peformansi. Doktorska disertacija, Ekonomski fakultet Split, Spli-Unpublished PhD thesis.

Bochenek, L. M., \& Blili, S. (2013). Profiling corporate communications strategy: Mastering organisational learning-A dynamic maturity model for corporate communications strategic management. The Marketing Review, 13(2), 143-165.

Bütschi, G., \& Steyn, B. (2006). Theory on strategic communication management is the key to unlocking the boardroom. Journal of Communication Management, 10(1), 106-109.

Chang, Y. (2009). An exploration of the standardization of targeting strategies and the use of promotional disciplines on the web: A cross-national study. Journal of Marketing Communications, 15(5), 327-343.

Cornelissen, J. (2008). Corporate Communication: A Guide to Theory and Practice. London: Sage publication.

Dolphin, R. R. (2002). A profile of PR directors in British companies. Corporate Communications: An International Journal, 7(1), 17-24.

Einwiller, S. A., \& Boenigk, M. (2013). Examining the link between integrated communication management and communication effectiveness in medium-sized enterprises. Journal of Marketing Communications, 18(5), 335-361.

Erickson, S. L., Weber, M., \& Segovia, J. (2011). Using Communication Theory to Analyze Corporate Reporting Strategies. Journal of Business Communication, 48(2), 207-223.

Fombrun, C. J., \& Rindova, V. (1998). Reputation Management in Global 1000 Firms: A Benchmarking Study. Corporate Reputation Review, 1(3), 205-212.

Goodman, M. B. (1998). Corporate communication for executives. New York: State University of New York Press.

Goodman, M. B. (2000). Corporate communication: The American picture. Corporate Communication: An International Journal, 5(2), 69-74.

Goodman, M. B. (2004). Current trends in corporate communication. Corporate Communication: An International Journal, 6(3), 117-123.

Goodman, M. B. (2006). Corporate communication practice and pedagogy at dawn of the new millennium. Corporate Communications: An international Journal, 11(7), 196-213.

Goodman, M. B. (2007). Challenges for corporate communication. Papers from the CCI Conference on Corporate Communication. 
Grunig, J. E. (1990). Theory and Practice of Interactive Media Relations. Public Relations Quarterly, $35(3), 18-23$.

Gruning, L. A. (2000). Public relation research: A tripartite model. Corporate Communications: An International Journal, 5(2), 75-80.

Halliburton, C., \& Ziegfeld, A. (2009). How do major European companies communicate their corporate identity across countries? An empirical investigation of corporate internet communications. Journal of Marketing Management, 25(9-10), 909-925.

Holm, O. (2006). Integrated marketing communication: From tactics to strategy. Corporate Communications: An International Journal, 11(1), 23-33.

Kim, S. (2011). Transferring Effects of CSR Strategy on Consumers Responses: The Synergetic Model of Corporate Communication Strategy. Journal of Public Relations Research, 23(2), 218-241.

Kitchen, P. J. (1997). Was public relations a prelude to corporate communications? Corporate Communications: An International Journal, 2(1), 22-30.

Kliatchko, J. (2008). Revisiting the IMC construct: A revised definition and four pillars. International Journal of Advertising, 27(1), 113-160.

Laurie, S., \& Mortimer, K. (2011). "IMC is dead. Long live IMC": Academics' versus practitioners' views. Journal of Marketing Management, 27(13-14), 1464-1478.

Rindova, V. P., \& Fombrun, J. (1999). Constructing competitive advantage: The role of firm-constituent interaction. Strategic Management Journal, 20(8), 691-710.

Schultz, E. (2000). The marketing game: How the world's best companies play to WIN. London: Kogan Page.

Šerić, M., Gil-Saura, I., \& Ruiz-Molina, M. E. (2014). How can integrated marketing communications and advanced technology influence the creation of customer-based brand equity? Evidence from the hospitality industry. International Journal of Hospitality Management, 39, 144-156.

Smith, P., Berry, C., \& Pulford, A. (2002). Strategic marketing communications: New ways to build and integrate communications. London: Kogan Page.

Steiner, C. J. (2001). How important is professionalism to corporate communication? Corporate Communications: An International Journal, 6(3), 150-156.

van Riel, C. B. M., \& Fombrun, J. (2007). Essentials of Corporate Communication: Implementing Practices for Effective Reputation Management. Abingdon: Routledge. 